\title{
PENGEMBANGAN PERANGKAT IOT MONITORING KUALITAS UDARA DALAM RUANGAN MENGGUNAKAN MIKROKONTROLLER BERBASIS ANDROID
}

\author{
Nogar Silitonga ${ }^{\bowtie}$, Yuniman Telaumbanua, Harlen Gilbert Simanullang \\ Teknik Informatika, Universitas Methodist Indonesia, Medan, Indonesia \\ Email: nogarsilitonga@gmail.com
}

DOI: https://doi.org/10.46880/jmika.Vol5No1.pp81-85

\begin{abstract}
Air quality in a room is a problem that needs to be considered because it can affect human health. Therefore, we need a system that can monitor $L P G, C O 2$, and cigarette smoke levels to determine the value of air quality levels in a room. Air pollution levels can be measured with the MQ-2 sensor to detect levels and an Android-based application as an information viewer. This study aims to build a monitoring application for LPG, CO2, and cigarette smoke levels based on the wireless ESP8266 sensor network in the room. The level monitoring application is built with the Java programming language, Firebase, and Arduino software. The application development stage includes analysis, system design, implementation, and testing. The level monitoring application that is made can display the results of monitoring data. So those users can find out the measurement data of a level that is in a room with a series of sensors used. The result is research on the use of this device can be used as a tool to monitor air quality in a room.
\end{abstract}

Keyword: ATMega328 Microcontroller, MQ-2 Sensor, Arduino IDE, Wireless ESP8266.

\begin{abstract}
ABSTRAK
Kualitas udara dalam suatu ruangan merupakan masalah yang perlu diperhatikan karena dapat mempengaruhi kesehatan manusia. Oleh karena itu, diperlukan suatu sistem yang dapat memonitoring kadar LPG, CO2, dan asap rokok untuk mengetahui nilai kadar kualitas udara pada suatu ruangan. Tingkat polusi udara dapat diukur dengan sensor MQ-2 untuk mendeteksi tingkat dan aplikasi berbasis Android sebagai penampil informasi. Penelitian ini bertujuan untuk membangun aplikasi monitoring kadar LPG, CO2, dan asap rokok berbasis jaringan sensor wireless ESP8266 di dalam ruangan. Aplikasi monitoring level dibangun dengan bahasa pemrograman Java, Firebase, dan software Arduino. Tahap pengembangan aplikasi meliputi analisis, perancangan sistem, implementasi, dan pengujian. Aplikasi monitoring level yang dibuat dapat menampilkan hasil data monitoring. Sehingga pengguna dapat mengetahui data pengukuran suatu level yang ada pada suatu ruangan dengan rangkaian sensor yang digunakan. Hasil penelitian penggunaan alat ini dapat digunakan sebagai alat untuk memantau kualitas udara dalam suatu ruangan.
\end{abstract}

Kata Kunci: Mikrokontroler ATMega328, Sensor MQ-2, Arduino IDE, Wireless ESP8266

\section{PENDAHULUAN}

Dalam kehidupan sehari-hari banyak aktivitas yang dilakukan didalam suatu ruangan tertentu agar memberikan kenyamanan untuk diri sendiri. Dimana faktor yang mempengaruhi kenyamanan pada ruangan adalah suhu dan kelembaban udara. Udara mengandung oksigen yang dibutuhkan untuk keberlangsungan hidup. Namun selain oksigen, terdapat beberapa zat lainnya yang terdapat di udara seperti karbon monoksida, karbon dioksida, formaldehid, jamur, virus, bakteri, debu dan sebagainya. Oksigen di dalam maupun di luar ruangan dapat terkontaminasi dengan zat-zat yang berbahaya bagi kesehatan. Dalam kasus tertentu kadar zat tersebut masih dapat dinetralisir namun jika melampaui batas normal maka dapat mengganggu kesehatan tubuh (Raharjo, 2009). World Health Organization (WHO) menyatakan bahwa terdapat zat berbahaya yang berasal dari bangunan, material konstruksi, peralatan, proses pembakaran atau pemanasan dapat memicu masalah Kesehatan (World Health Organization, 2014). Meningkatnya aktivitas manusia memicu masalah pencemaran udara, sehingga dibutuhkansuatu solusi yang dapat menurunkan gangguan pencemaran udara. Pada saat tertentu manusia dapat memperkirakan jika udara berada pada level normal atau tidak dengan menggunakan indera. Tetapi dibutuhkan suatu alat berupa perangkat keras yang 
dapat memantau kelembaban udara secara real time agar mendapatkan data mengenai kualitas udara.

Oleh karena itu, pemantauan terhadap tingkat kualitas udara melalui Smartphone sangat dibutuhkan sehingga informasi mengenai kualitas udara dapat diakses dengan mudah oleh penggunanya untuk memperoleh informasi mengenai kualitas udara.

\section{TINJAUAN PUSTAKA}

Beberapa referensi penelitian yang digunakan oleh penulis dalam penelitian ini diantaranya monitoring kebocoran gas menggunakan microcontroller Arduino dan esp8266 berbasi IoT dimana alat yang dibangun dapat mendeteksi kebocoran gas secara efektif (Roihan, Permana, \& Mila, 2016), penerapan IoT pada monitoring infus dengan tingak kesalahan yang kecil $(2,46 \%)$ dalam mendeteksi volume infus pada penggujiannya (Sasmoko \& Wicaksono, 2017) dan monitoring tangki SPBU berbasis IoT yang dapat mengirimkan kondisi tangki dan menyalakan alarm pada tingkat tangki yang kosong (Sorongan, Hidayati, \& Priyono, 2018).

\section{METODE PENELITIAN}

Pada awal perancangan sistem perangkat IoT yakni dengan melakukan perancangan model yang akan dibangun. Sistem yang akan dibangun menggunakan Arduino Uno dengan Mikrokontroller Atmega 328 sebagai modul utama, dengantambahan modul wifi ESP8266 sebagai penghubung antara Arduino Uno dengan perangkat Android pengguna. Data yang di-terima oleh perangkat akan dikirim melalui wifi untuk kemudian di-tampilkan pada perangkat Android berupa aplikasi sebagai monitoring kondisi udara di sekitar.

Sedangkan sensor MQ-2 berfungsi sebagai penerima input untuk mendeteksi gas yang berada pada daerah sekitar dengan range tertentu yang akan diukur dari ppm (part per million). Sensor tersebut dapat mendeteksi konsentrasi gas yang terdapat pada udara yang memiliki karakter mudah terbakar diudara mulai dari $300-10.000$ ppm. Setelah gas terdeteksi oleh sensor, maka selanjutnya sensor akan mengirim informasi (input) kepada Arduino Uno kemudian informasi yang telah di-olah akan di-kirim ke smartphone pengguna melalui modul WifiESP8266. Data yang diterima pengguna berupa informasi konsentrasi gas di udara (part per million)yang berguna sebagai monitoring udara di sekitar perangkat IoT.

Data yang dikirim akan ditampilkan pada perangkat Android berupa aplikasi yang dapat diinstallkan.

\section{PERANCANGAN SISTEM}

Perancangan sistem merupakan gambaran dari beberapai rangkaian aktivitas yang digambarkan secara rinci bagaimana sistem akan berjalan, merancang detail dan rincian dari sistem yang akan dibuat sehingga sistem dapat menyesuaikan dengan requirement yang sudah ditetapkan dalam tahap analisa sistem. Pada perangkat keras, terdapatbeberapa modul yaitu sensor MQ-2, ATMega328, objek kendali dan output sistem. Sensor MQ -2 sebagai input yang berisi nilai dari konsentrasi udara di sekitar yang kemudian informasi tersebut dikirim ke perangkat Arduino Uno.

Informasi kualitas diterima oleh sensor MQ-2 berupa nilai float, kemudian nilai yang telah dibaca oleh Arduino akan dikirim ke perangkat Android dengan menggunakan modul Wifi ESP8266. Setelah perangkat terdeteksi, Android pengguna akan menerima informasi yang akan ditampilkan pada perangkat Android dengan tampilan yang interaktif. Jika nilai yang diterima dari sensor masih berada dibawah ambang batas (threshold) maka informasi dari sensor akan menghasilkan kualitas udara baik, sebaliknya jika nilai yang diterima dari sensor melewati ambang batas (threshold) maka akan menghasilkan kualitas udara berbahaya dan akan mengirimkan umpan balik (feedback) kepada alat agar mengaktifkan kipas untuk membuat udara yangberada pada area sekitar ruangan. Model perancangan perangkat monitoring kualitas udara dapat dilihat pada gambar 1.

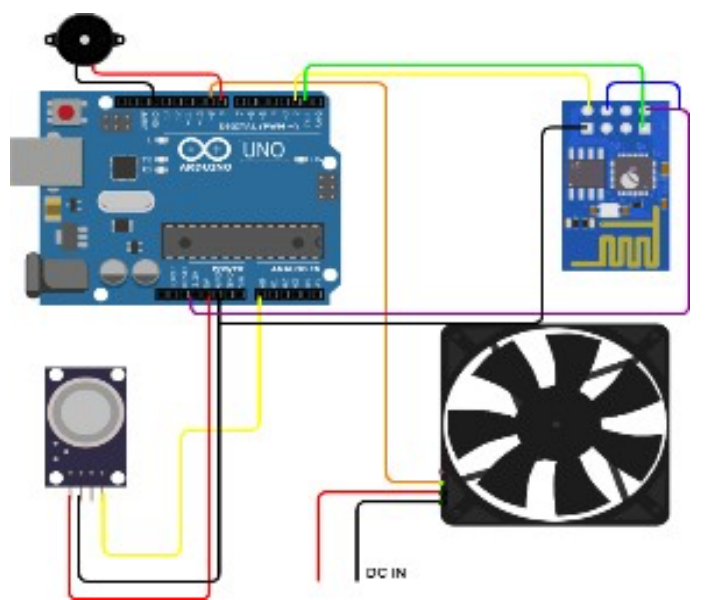

Gambar 1. Model Perancangan MonitoringKualitas Udara

\section{Use-Case Diagram}

Perancangan use-case diagram untuk monitoring udara ditampilkan pada gambar 2 berikut: 


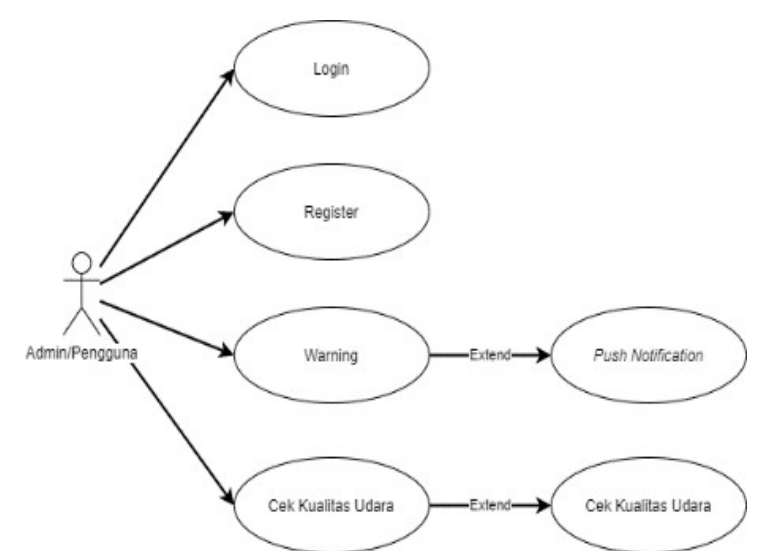

Gambar 2. Use-Case Diagram Monitoring Udara

\section{Flowchart Sistem}

Flowchat dari sistem pada aplikasi monitoring udara ditampilkan pada gambar 3 berikut

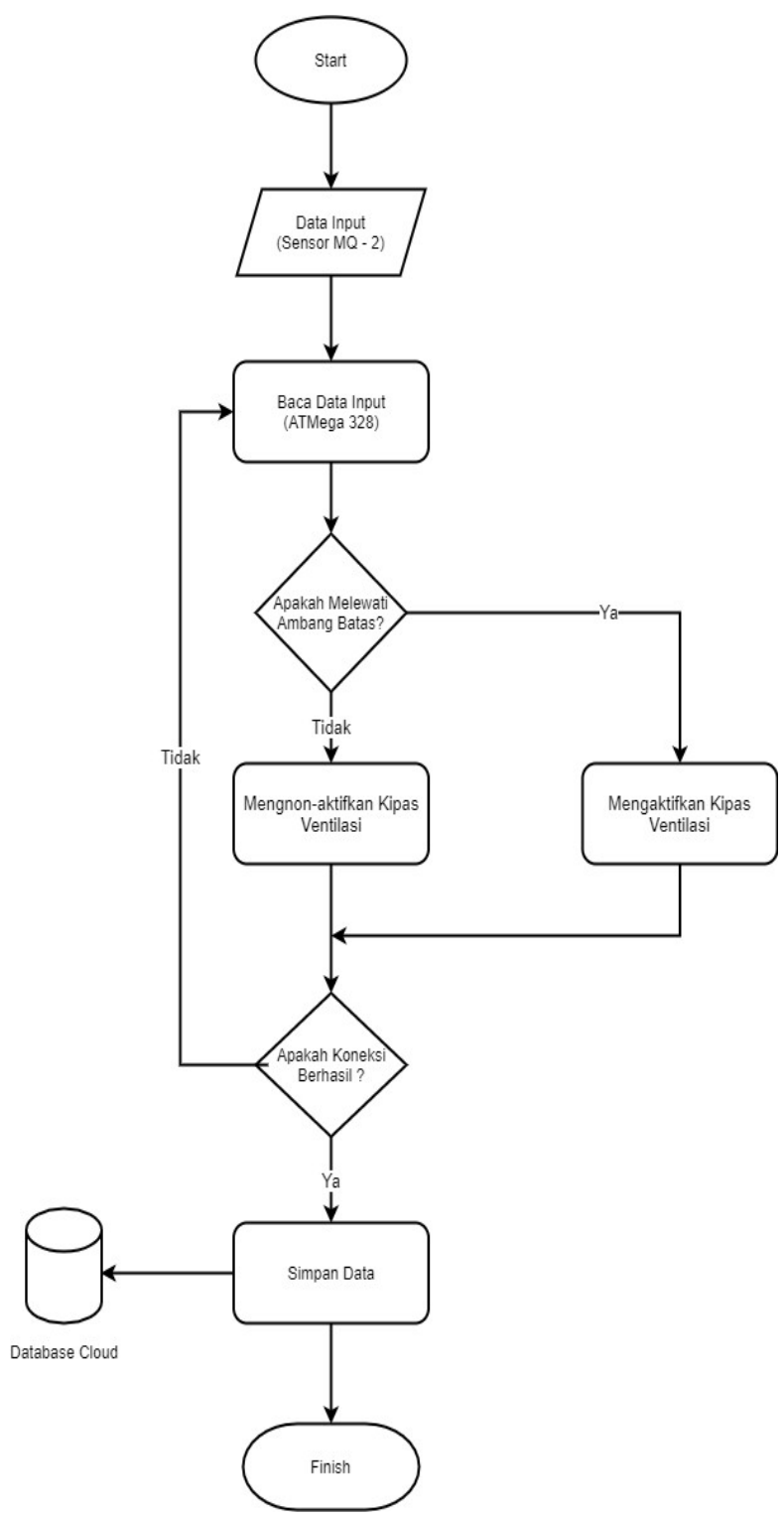

Gambar 4. Flowchart Sistem Monitoring Udara

\section{Entity Relationship Diagram (ERD)}

Perancangan entity relationship diagram pada aplikasi monitoring udara ditampilkan pada gambar 3 berikut

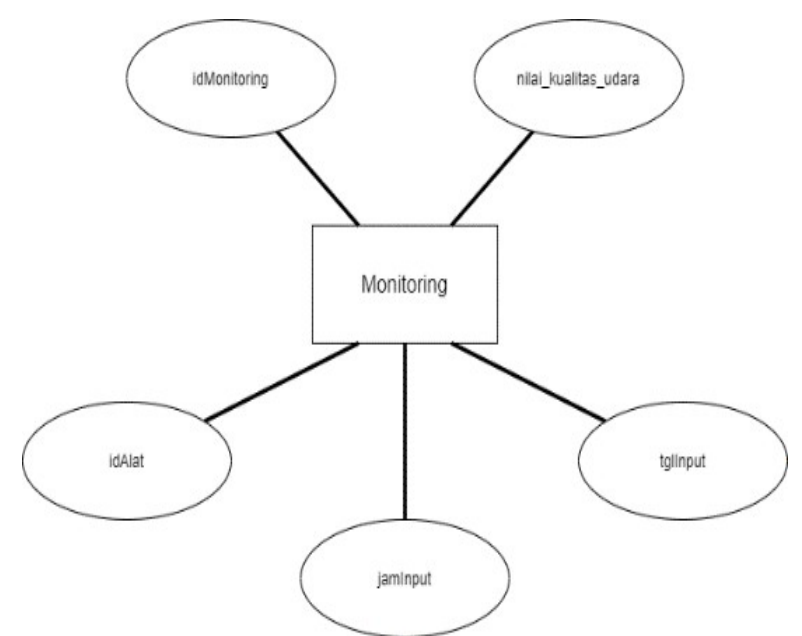

Gambar 3. ERD Monitoring Udara

\section{IMPLEMENTASI}

Tampilan Halaman Utama

Berikut ini merupakan tampilan halaman utama dari aplikasi monitoring kualitas udara:

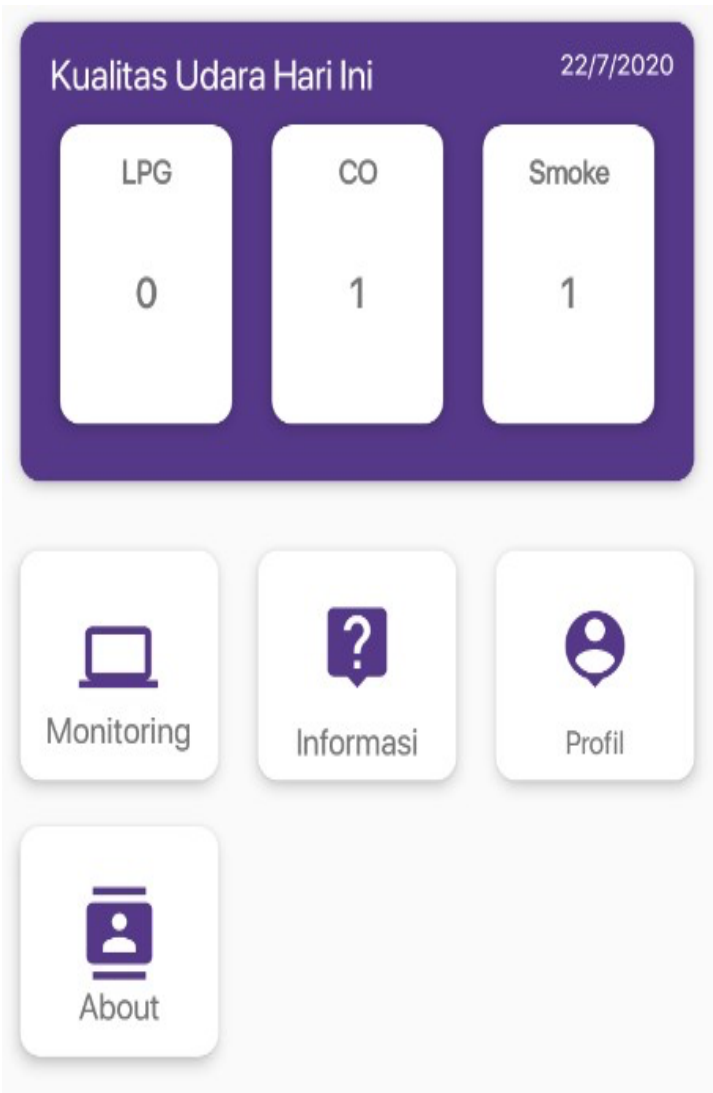

Gambar 5. Tampilan Halaman Utama 


\section{Tampilan Monitoring}

Tampilan monitoring pada aplikasi android dapat dilihat pada gambar 6 berikut:
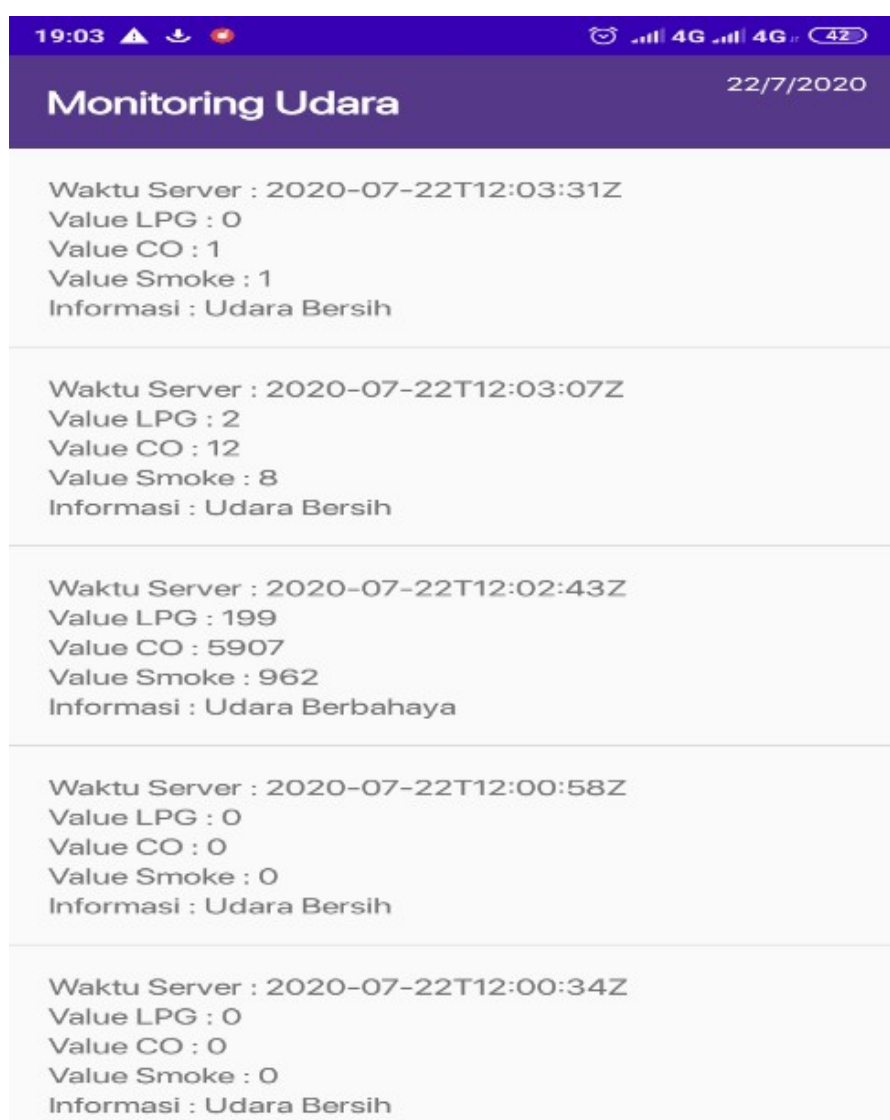

Gambar 6. Tampilan Monitoring

\section{Skema Pengujian Sistem}

Dalam pengujian saat mendeteksi LPG, CO, Asap Rokok dilakukan 10 pengujian. Percobaan dilakukan dalam sehari dengan perubahan waktu per5 detik. Hasil pengujian dapat dilihat pada table 1 berikut:

Tabel 1. Pengujian Mendeteksi Kualitas Udara

\begin{tabular}{|l|c|c|c|c|c|}
\hline & Waktu & $\begin{array}{c}\text { LPG } \\
(\mathbf{p p m})\end{array}$ & $\begin{array}{c}\text { CO } \\
(\mathbf{p p m})\end{array}$ & $\begin{array}{c}\text { Asap Rokok } \\
\mathbf{( p p m )}\end{array}$ & Kondisi \\
\hline GET / update $: 1$ & 16.34 .01 & 10 & 112 & 49 & Udara bersih \\
\hline GET / update $: 2$ & 16.34 .24 & 33 & 3 & 3 & Udara bersih \\
\hline GET / update $: 3$ & 16.34 .48 & 7 & 59 & 28 & Udara bersih \\
\hline GET /update $: 4$ & 16.35 .12 & 2 & 15 & 10 & Udara bersih \\
\hline GET /update $: 5$ & 16.35 .36 & 1 & 7 & 6 & Udara bersih \\
\hline GET / update $: 6$ & 16.36 .00 & 1 & 8 & 6 & Udara bersih \\
\hline GET /update $: 7$ & 16.36 .24 & 1 & 8 & 6 & Udara bersih \\
\hline GET /update $: 8$ & 16.36 .48 & 2 & 12 & 8 & Udara bersih \\
\hline GET /update $: 9$ & 16.37 .13 & 1 & 8 & 6 & Udara bersih \\
\hline GET /update $: 10$ & 16.37 .37 & 0 & 3 & 3 & Udara bersih \\
\hline
\end{tabular}

\section{KESIMPULAN}

Dari perancangan dan pengujian yang telah dilakukan maka peneliti dapat menyimpulkan beberapa hal, diantaranya:
1. Dalam membangun aplikasi monitoring kualitas udara berbasis Internet of Things penulis menggunakan Wireless Fidelity ESP8266 sebagai pengolah data kadar gas berbahaya yang disimpan 
ke firebase. Penggunaan Wireless Fidelity ESP8266 sebagai Internet of Things memudahkan dalam melakukan instalasi perangkat, karena Wireless Fidelity ESP8266 sudah terdapat modul wifi yang berfungsi sebagai penghubung perangkat mikrokontroller dengan internet.

2. Cara kerja keseluruhan alat, alat terpasang pada sensor MQ-2 berfungsi sebagai inputan informasi terhadap gas pada ruangan yang kemudian inputan tersebut disimpan ke dalam database. Data yang terdapat pada database dijadikan sebagai monitoring setiap saat terhadap kondisi ruangan.

3. Dari hasil pengujian aplikasi monitoring kualitas udara berbasis Android, pengujian fungsionalitas semua fitur aplikasi monitoring kualitas udara berjalan sesuai yang diharapkan. Pengujian yang dilakukan pada suatu ruangan sudah dapat menentukan kondisi udara pada ruangan tersebut. Dari hasil uji portabilitas aplikasi monitoring kualitas udara dapat berjalan di sistem android versi Oreo dan Pie.

\section{DAFTAR PUSTAKA}

Raharjo, M. (2009). Dampak Pencemaran Udara pada Lingkungan dan Kesehatan Manusia. Universitas Diponegoro.

Roihan, A., Permana, A., \& Mila, D. (2016). Monitoring kebocoran gas menggunakan mikrokontroler arduino uno dan esp8266 berbasis internet of things. Innovative Creative and Information Technology, 2(2), 170-183.

Sasmoko, D., \& Wicaksono, Y. A. (2017). Implementasi Penerapan Internet Of Things (Iot) Pada Monitoring Infus Menggunakan Esp 8266 Dan Web Untuk Berbagi Data. Jurnal Ilmiah Informatika, 2(1), 90-98.

Sorongan, E., Hidayati, Q., \& Priyono, K. (2018). ThingSpeak sebagai Sistem Monitoring Tangki SPBU Berbasis Internet of Things. JTERA Jurnal Teknologi Rekayasa, 3(2), 219-224.

World Health Organization. (2014). WHO guidelines for indoor air quality: household fuel combustion. Genewa: World Health Organization. 